\title{
A review of the diagnosis and management of hyponatremia in connolly hospital: an audit of current practice and the construction of a clinical aid for the diagnosis and treatment of Hyponatremia
}

\author{
Neil McAuliffe $e^{1 *}$, Seamus Sreenan ${ }^{1,2}$ \\ From 4th International Conference for Healthcare and Medical Students (ICHAMS) 2014 \\ Dublin, Ireland. 24-25 October 2014
}

\section{Background}

Hyponatraemia is the most common example of body fluid and electrolyte imbalance encountered in clinical practice, and is associated with increased mortality, morbidity and length of hospital stay in patients [1]. In spite of this, the diagnosis and management of hyponatremia remains inconsistent as clinicians adopt a broad range of hospital- and specialty-specific approaches [1, 2]. In light of this observed inconsistency, the objectives of the present project were: (i) To audit all patients admitted to Connolly Hospital Blanchardstown (CHB) Emergency Department (ED) with hyponatremia $(<135 \mathrm{mmol} / \mathrm{L})$ over a 14 day period. (ii) Record the diagnostic and management methods employed, comparing them with recent guidelines published by the European Society of Endocrinology (ESE). (iii) To construct a clinical aid for the diagnosis and treatment of hyponatremia, specific to CHB.

\section{Methods}

The records of all patients admitted to the ED over a 14 day period $(\mathrm{N}=426)$ were studied. Those presenting with hyponatremia (serum sodium $<135 \mathrm{mmol} / \mathrm{L}$ ) upon initial measurement were identified and their lab results and patient files reviewed.

\section{Results}

Hyponatremia $(<135 \mathrm{mmol} / \mathrm{L})$ was observed in $10.7 \%$ of admitted patients $(n=46$; Sex: 12:34, M:F; Age: Mean : 63.4; Range: [16 - 98]) on initial measurement. Of these, $63 \%$ had mild (130-135 mmol/L), $19.6 \%$ moderate

${ }^{1}$ Royal College of Surgeons in Ireland, Dublin, Ireland

Full list of author information is available at the end of the article
$(125-129)$ and $17.4 \%$ profound $(<125)$ hyponatremia respectively. In $41 \%$ of cases $(18 / 44)$ inappropriate or insufficient diagnostic methods were utilised, when compared with the ESE guidelines. Blood glucose was measured in $69.5 \%(32 / 46)$ of patients, $32.6 \%(15 / 46)$ had Thyroid Function Tests and 17.3\% (8/46) had Serum Cortisol measured. In $9 \%$ of cases $(4 / 44)$ the management employed was inconsistent with the guidelines. In addition, 2 incidences (4.5\%) of rapid overcorrection of sodium were observed $(>10 \mathrm{mmol} / \mathrm{L}$ for the first 24 hours and $>8$ for any 24 hours thereafter).

\section{Conclusions}

Analysis of the data revealed that while the management of hyponatremic patients was largely consistent with ESE guidelines, the diagnostic procedures in many cases were not. These results confirm the need for a diagnostic and management algorithm in $\mathrm{CHB}$, and given the consistency of results across other institutions, the implementation of ESE guidelines in other centres may yield improved patient care and outcomes.

\section{Authors' details \\ ${ }^{1}$ Royal College of Surgeons in Ireland, Dublin, Ireland. ${ }^{2}$ Connolly Hospital Blanchardstown, Dublin, Ireland.}

\section{Published: 27 October 2015}

\section{References}

1. Spasovski G, Vanholder R, Allolio B, Annane D, Ball S, Bichet D, Decaux G, Fenske W, Hoorn E, Ichai $C$, et al: Clinical practice guideline on diagnosis and treatment of hyponatraemia. Eur J Endocrinol 2014, 170(3):G1-47.

2. Tzamaloukas A, Malhotra D, Bradley H, Dominic S, Murata G, Shapiro J: Principles of Management of Severe Hyponatemia. J Am Heart Assoc 2013, doi: 10.1161/JAHA.112.005199. 
doi:10.1186/1753-6561-9-S7-A16

Cite this article as: McAuliffe and Sreenan: A review of the diagnosis and management of hyponatremia in connolly hospital: an audit of current practice and the construction of a clinical aid for the diagnosis and treatment of Hyponatremia. BMC Proceedings 2015 9(Suppl 7):A16.

Submit your next manuscript to BioMed Central and take full advantage of:

- Convenient online submission

- Thorough peer review

- No space constraints or color figure charges

- Immediate publication on acceptance

- Inclusion in PubMed, CAS, Scopus and Google Scholar

- Research which is freely available for redistribution

Submit your manuscript at www.biomedcentral.com/submit
Ciomed Central 